\title{
PENGARUH KOMITMEN DAN PENDAPATAN TERHADAP KEBERSAMAAN DAN DAMPAKNYA TERHADAP KINERJA PEGAWAI SEKRETARIAT DEWAN PERWAKILAN RAKYAT DAERAH KOTA PEKANBARU
}

\author{
Novita \\ Sekolah Tinggi Ilmu Ekonomi Riau \\ Jl. HR Subrantas KM 12 Panam Pekanbaru \\ Email: novitaq8@gmail.com
}

\begin{abstract}
ABSTRAK Tujuan penelitian ini adalah untuk mengetahui pengaruh komitmen, pendapatan dan kebersamaan terhadap kinerja pegawai. Selain itu juga untuk mengetahui pengaruh komitmen dan pendapatan secara bersama-sama terhadap kebersamaan pegawai dan juga untuk mengetahui pengaruh komitmen, pendapatan dan kebersamaan secara bersama-sama terhadap kinerja pegawai di Sekretariat DPRD Kota Pekanbaru. Objek penelitian ini adalah para pegawai di Sekretariat DPRD Kota Pekanbaru sebanyak 56 orang yang diambil secara sensus dari seluruh pegawai. Variabel yang diteliti terdiri dari tiga variabel bebas dan satu variabel terikat. Variabel bebas adalah komitmen $\left(\mathrm{X}_{1}\right)$, pendapatan $\left(\mathrm{X}_{2}\right)$ dan kebersamaan $\left(\mathrm{X}_{3}\right)$, sedangkan variabel terikat adalah kinerja pegawai $(\mathrm{Y})$. Metode penelitian yang digunakan dalam penelitian ini adalah metode kuantitatif. Instrumen yang digunakan untuk pengumpulan data berbentuk angket model skala likert. Pembahasan dan pengujian hipotesis yang dilakukan melalui teknik analisis jalur yang pengolahannya menggunakan program SPSS 17. Hasil penelitian menunjukkan besarnya pengaruh komitmen terhadap kebersamaan sebesar $0,350^{2} \times 100 \%=12,25 \%$. Besarnya pengaruh pendapatan terhadap kebersamaan sebesar $0,560^{2} \mathrm{x}$ $100 \%=31,36 \%$. Besarnya pengaruh komitmen yang secara langsung mempengaruhi kinerja sebesar $0,260^{2} \times 100 \%=6,76 \%$. Besarnya pengaruh pendapatan yang secara langsung mempengaruhi kinerja sebesar $0,316^{2} \times 100 \%=9,98 \%$. Besarnya pengaruh kebersamaan yang secara langsung mempengaruhi kinerja sebesar $0,329^{2}$ x $100 \%=10,82 \%$. Pengaruh tidak langsung $\mathrm{X}_{1}$ terhadap $\mathrm{Y}$ melalui $\mathrm{X}_{3}$ sebesar $\rho \mathrm{x}_{3} \mathrm{X}_{1}$. $\rho \mathrm{yx}_{3}=(0,350) \cdot(0,329)=0,115$. Dengan demikian pengaruh total $\mathrm{X} 1$ terhadap $\mathrm{Y}$ adalah sebesar 0,115. Selanjutnya pengaruh tidak langsung $\mathrm{X}_{2}$ terhadap $\mathrm{Y}$ melalui $\mathrm{X}_{3}$ sebesar $\rho \mathrm{x}_{3} \mathrm{x}_{2} . \rho \mathrm{yx}_{3}=(0,560) .(0,329)=0,184$. Dengan demikian pengaruh total $\mathrm{X}_{2}$ terhadap $\mathrm{Y}$ adalah sebesar 0,184 . Dengan demikian diketahui jalur yang memberikan pengaruh yang lebih besar terhadap kinerja adalah jalur variabel pendapatan melalui variabel kebersamaan.
\end{abstract}

Kata Kunci: Komitmen, Pendapatan, Kebersamaan, Kinerja Pegawai

\begin{abstract}
This research is to know the influence commitment and income to solidarity and effect to officer performance in DPRD Secretariat of Pekanbaru either through individual and also by together. This research was conducted at DPRD Secretariat of Pekanbaru. The object of this Research is all officer in DPRD Secretariat of Pekanbaru as 56 person's who is taken in census from all person. The independent variable is three and one dependent variable, it is variable commitment $\left(\mathrm{X}_{1}\right)$, income $\left(\mathrm{X}_{2}\right)$ and solidarity $\left(\mathrm{X}_{3}\right)$, while dependent variable is officer performance $(\mathrm{Y})$. Research method used in this research is quantitative method. Instrument used for data collecting is in form of questionnaire model likert's scale. The hypothesis examination and solution done through doubled technique regression which its processing use program computer with program SPSS version 17, hence got the result expressing that influence organizational commitment to the solidarity of equal to $0,350^{2} \times 100 \%=12,25 \%$. The influence income to the solidarity of equal to $0,560^{2} \times 100 \%=31,36 \%$. The influence commitment to the officer performance of equal to $0,260^{2} \times 100 \%=6,76 \%$. The influence earnings to the officer
\end{abstract}


performance of equal to $0,316^{2} \times 100 \%=9,98 \%$. The influence solidarity to the officer performance of equal to $0,329^{2} \times 100 \%=10,82 \%$. Indirect influence of commitment to the officer performance of solidarity of equal to $\rho \mathrm{x}_{3} \mathrm{x}_{1}$. $\rho \mathrm{px}_{3}=(0,350)$. $(0,329)=0,115$. So, total influence commitment to the officer performance of equal to 0,115 . Indirect influence income to the officer performance of solidarity of equal to $\rho \mathrm{x}_{3} \mathrm{x}_{2} \cdot \rho \mathrm{yx} \mathrm{x}_{3}=(0,560) \cdot(0,329)=0,184$. So, total influence income to the officer performance of equal to 0,184 . So, good path analysis that influence bigger to the officer performance is income of solidarity.

Key words : commitment, income, solidarity, performance

\section{PENDAHULUAN}

Rendahnya kualitas sumber daya manusia juga akan menjadi batu sandungan dalam era globalisasi, dimana era globalisasi merupakan era persaingan mutu. Jika bangsa Indonesia ingin berkiprah dalam percaturan global, maka langkah pertama yang harus dilakukan adalah menata sumber daya manusia, baik dari aspek intelektual, spiritual, kreativitas, moral, maupun tanggung jawab. Pegawai adalah manusia yang mempunyai sifat kemanusiaan, perasaan dan kebutuhan yang beraneka ragam. Kebutuhan ini bersifat fisik maupun non fisik yang harus dipenuhi agar dapat hidup secara layak dan manusiawi. Hal ini menyebabkan timbulnya suatu pendekatan yang berdasarkan pada kesejahteraan pegawai dalam manajemen personalia. Pegawai harus mendapatkan perlakuan sedemikian rupa sehingga kerjasama antara pimpinan dan bawahan dapat terjalin dengan baik.

Komunikasi yang baik diperlukan dalam rangka menjalin hubungan antara atasan dengan bawahan untuk keberhasilan suatu organisasi dalam mencapai tujuan yang telah ditetapkan. Kondisi ini dinilai penting dan memberikan kontribusi positif. Sebagai manusia, pegawai juga mempunyai tujuan sehingga diperlukan suatu integrasi antara tujuan organisasi dengan tujuan pegawai. Untuk mengusahakan integrasi antara tujuan organisasi dan tujuan pegawai, perlu diketahui apa yang menjadi kebutuhan masing-masing pihak. Kebutuhan pegawai diusahakan dapat terpenuhi melalui pekerjaannya. Apabila seorang pegawai sudah terpenuhi segala kebutuhannya maka dia akan mencapai kepuasan kerja dan memiliki komitmen terhadap organisasi. Tingginya komitmen pegawai dapat mempengaruhi usaha suatu organisasi secara positif. Adanya komitmen akan membuat pegawai mendukung semua kegiatan organisasi secara aktif, ini berarti pegawai akan bekerja lebih produktif.

Berdasarkan fenomena yang ada berkaitan dengan kinerja pegawai ditemui gejala-gejala sebagai berikut : 70\% kegiatan perjalanan dinas keluar kota diberikan kepada pegawai yang sama, hal ini menunjukkan adanya kecenderungan persaingan yang tidak sehat, sehingga cenderung untuk saling memperebutkan dan juga menyebabkan pegawai kurang kompak dalam bekerja dengan kurangnya kerjasama antar pegawai dalam menyelesaikan sebuah pekerjaan yang menjadi tanggung jawab organisasi. Pegawai golongan III yang tidak memiliki jabatan (20\%) padahal memenuhi syarat pangkat dan golongannya serta masalah ada sebagian pegawai yang bekerja dengan intensitas kerja yang padat sedangkan sebagian lainnya tidak ada sesibuk pegawai tersebut. Pegawai yang dalam 
memegang jabatan tidak sesuai (35\%) dengan pendidikan yang diperolehnya, sehingga pegawai tersebut merasa kurang mampu untuk mengaktualisasikan dirinya dalam bekerja. Pegawai cenderung kurang peduli (30\%) dengan pekerjaan yang menjadi tanggung jawabnya dan lebih mengutamakan kepentingan pribadinya atau keluarganya seperti menjemput anak dan mengantar ke sekolah, belanja dan lainnya.

Bertitik tolak dari uraian di atas dan fenomena yang telah dipaparkan, maka penulis tertarik untuk melakukan penelitian yang lebih mendalam dengan judul "Pengaruh komitmen dan pendapatan terhadap kebersamaan dan dampaknya terhadap kinerja pegawai Sekretariat DPRD Kota Pekanbaru".

\section{TINJAUAN PUSTAKA}

\section{Kinerja Pegawai}

Terdapat banyak pendapat yang berbicara tentang kinerja, dimana pada dasarnya kinerja merupakan hasil kerja yang dicapai seseorang dalam melakukan suatu pekerjaan, apakah kinerja tersebut maksimal atau tidak tergantung dari kemampuan diri pekerja itu sendiri. Kinerja pegawai berbeda dengan kinerja organisasi, kinerja pegawai mengarah kepada hasil yang dicapai pada setiap pegawai, sedangkan kinerja organisasi merupakan hasil secara akumulasi dari yang dihasilkan pegawai dalam sebuah organisasi. Berikut ini beberapa pendapat ahli tentang definisi, arti penting dan ukuran kinerja. Definisi kinerja pegawai menurut Tika (2005: 121) menyatakan kinerja sebagai hasil fungsi pekerjaan/kegiatan seseorang atau kelompok dalam suatu organisasi yang dipengaruhi oleh berbagai faktor untuk mencapai tujuan organisasi dalam periode waktu tertentu.

Kemudian Lawler dan Porter dalam Sutrisno (2010: 170) menyatakan kinerja adalah kesuksesan seseorang dalam melaksanakan tugas. Kemudian menurut Miner dalam Sutrisno (2010: 170) menyatakan kinerja adalah bagaimana seseorang diharapkan dapat berfungsi dan berperilaku sesuai dengan tugas yang telah dibebankan kepadanya. Widodo (2001: 47) bahwa kinerja adalah sesuatu yang dicapai, prestasi yang diperlihatkan dan kemampuan kerja. Kemudian menurut Mangkunegara, (2000: 67) istilah kinerja dari kata job performance atau actual performance (prestasi kerja atau prestasi, sesungguhnya yang dicapai seseorang). Pengertian kinerja adalah hasil kerja secara kualitas dan kuantitas yang dicapai oleh seseorang dalam melaksanakan tugasnya sesuai dengan tanggung jawab yang diberikan kepadanya. Selanjutnya dapat dipahami kinerja aparat mempengaruhi kinerja organisasi dimana dia berperan sebagai pelaku.

Menurut Soeprihanto (2000: 8), secara lebih rinci menyebutkan bahwa tujuan penilaian pelaksanaan pekerjaan (kinerja) sebagai berikut: 1) Mengetahui keadaan keterampilan dan kemampuan setiap pegawai secara rutin. 2) Untuk digunakan sebagai dasar perencanaan bidang personalia, khususnya penyempurnaan kondisi kerja, peningkatan mutu dan hasil kerja. 3) Dapat digunakan sebagai dasar pengembangan dan pendayagunaan pegawai seoptimal mungkin, sehingga antara lain dapat diarahkan jenjang karirnya atau perencanaan karir, kenaikan pangkat dan kenaikan jabatan. 4) Mendorong terjadinya hubungan timbal balik antara atasan dan bawahan. 5) Mengetahui kondisi organisasi secara 
keseluruhan dari bidang personalia, khususnya kinerja pegawai. 6) Secara pribadi pegawai dapat mengetahui kekuatan dan kelemahan masing-masing sehingga dapat memacu perkembangan. 7) Hasil evaluasi kinerja dapat bermanfaat bagi penelitian dan pengembangan di bidang personalia secara keseluruhan. Menurut Fatkhurahman (2018) bahwa kinerja sama juga dengan hasil yang dicapai.

Berdasarkan pendapat tersebut di atas, jelas dapat dikatakan bahwa kinerja adalah suatu kumpulan total dari perilaku kerja yang ada pada pekerja, dalam kaitannya dengan kinerja pegawai yaitu perilaku kerja pegawai. Pentingnya kinerja pegawai berkaitan dengan pencapaian kinerja organisasi, pegawai yang memiliki kinerja yang baik, akan menyebabkan kinerja organisasi juga semakin baik.

Ukuran kinerja pegawai yang digunakan dalam penelitian ini adalah menurut Surya Dharma (2004: 514-515) yang menyebutkan bahwa teknik penilaian kinerja pegawai yang paling sederhana dan paling populer adalah skala pengharkatan grafik. Dimana kinerja pegawai dapat dilihat dari 1) kualitas (yang meliputi: akurasi, ketelitian, penampilan dan penerimaan keluaran, 2) kuantitas (yang meliputi: volume keluaran dan kontribusi), 3) supervisi yang diperlukan (yang meliputi: (membutuhkan saran, arahan dan perbaikan), 4) kehadiran (yang meliputi: regularitas, dapat dipercayai/diandalkan dan ketepatan waktu) dan 5) konservasi (yang meliputi: pencegahan pemborosan, kerusakan dan pemeliharaan peralatan). Pendapat ini juga didukung oleh pendapat Prawirosentono dalam Sianipar dan Entang (2001: 5) menyatakan bahwa pada prinsipnya kinerja unitunit organisasi dimana seseorang atau sekelompok orang (group of human being) berada didalamnya merupakan pencerminan dari kinerja sumberdaya manusia yang bersangkutan. Dengan demikian pokok utama yang harus dinilai kinerjanya adalah unsur manusia, karena merekalah yang berperan didalamnya. Mereka merupakan sumber daya yang sangat berperan dalam menentukan kinerja organisasi. Kinerja dapat berupa produk akhir (barang dan jasa) dan atau berbentuk perilaku, kecakapan, kompensasi, sarana dan keterampilan spesifik yang dapat mendukung pencapaian tujuan dan sasaran organisasi.

Lebih lanjut Siagian, (2008: 224) menyatakan penilaian kinerja perlu dilakukan secara formal berdasarkan kriteria yang ditetapkan secara objektif serta didokumentasikan secara sistematik. Jadi penilaian kinerja ini diperlukan untuk menentukan tingkat kontribusi individu. Selanjutnya menurut Dessler (2004: 521) mengemukakan bahwa faktor-faktor umum yang dinilai dalam kinerja meliputi: pengetahuan, kehati-hatian, keterampilan, kemampuan dan pengamatan. Dari pendapat di atas, maka ukuran kinerja pegawai yang digunakan dalam penelitian ini adalah menurut Surya Dharma yang menyebutkan bahwa teknik penilaian kinerja pegawai yang paling sederhana dan paling populer adalah skala pengharkatan grafik. Dimana kinerja pegawai dapat dilihat dari: kualitas (yang meliputi: akurasi, ketelitian, penampilan dan penerimaan keluaran. kuantitas (yang meliputi: volume keluaran dan kontribusi). supervisi yang diperlukan (yang meliputi: (membutuhkan saran, arahan dan perbaikan). kehadiran (yang meliputi: regularitas, dapat dipercayai/diandalkan dan ketepatan waktu). konservasi (yang meliputi: pencegahan pemborosan, kerusakan dan pemeliharaan peralatan). 
Kemudian dibahas juga berkenaan dengan faktor yang mempengaruhi kinerja pegawai, diantaranya: visi-misi, struktur organisasi, prosedur kerja, sistem intensif, disiplin, kerjasama, kebersamaan, kepemimpinan dan lain-lain. Hal tersebut telah dibuktikan dengan berbagi penelitian. Menurut Tika (2005: 122) faktor yang mempengaruhi hasil pekerjaan seseorang atau sekelompok orang terdiri dari faktor intern dan faktor ekstern. Faktor intern yang mempengaruhi kinerja karyawan/kelompok terdiri dari kecerdasan, ketrampilan, kestabilan emosi, motivasi (dapat berupa gaji), persepsi peran, kondisi keluarga, kondisi fisik seseorang dan karakteristik kelompok kerja, dan sebagainya. Sedangkan pengaruh eksternal antara lain berupa peraturan ketenagakerjaan, keinginan pelanggan, pesaing, nilai-nilai sosial, serikat buruh, kondisi ekonomi, perubahan lokasi kerja dan kondisi pasar.

Kemudian menurut Mathis dan Jackson (2001: 82) banyak faktor yang mempengaruhi kinerja dari individu tenaga kerja antara lain kemampuan mereka, motivasi, dukungan yang diterima, keberadaan pekerjaan yang mereka lakukan dan hubungan atau kebersamaan mereka dengan organisasi. Berdasarkan pendapat di atas, kinerja pegawai dipengaruhi oleh banyak hal, yang mana faktor yang menonjol adalah kecakapan serta pengetahuan seseorang, sedangkan kinerja kelompok juga sangat kompleknya, yang mana diantaranya adalah aspek kerjasama dan disiplin dalam melaksanakan tugasnya. Hal tersebut tentunya dibutuhkan sikap profesionalisme dalam bekerja. Menurut Robins (2001 : 273), bahwa: "Sejumlah faktor struktural menunjukkan suatu hubungan ke kinerja. Di antara faktor yang lebih menonjol adalah persepsi peran, norma, inekuitas status, ukuran kelompok, susunan demografinya, tugas kelompok dan kekohesifan (saling terkait)". Sedangkan menurut Mangkunegara (2002: 67) mengatakan bahwa faktor-faktor yang mempengaruhi kinerja pegawai adalah: 1) Faktor kemampuan dan 2) Faktor motivasi. Kemudian faktor-faktor yang mempengaruhi kinerja pegawai, secara rinci dikemukakan oleh Mangkunegara (2002: 67) menyatakan bahwa setiap usaha untuk mengetahui mengapa seseorang berprilaku seperti yang dilakukan selama ini dalam organisasi memerlukan pemahaman tentang: (1) individu yang memiliki kemampuan, keterampilan mencakup mental dan fisik, latar belakang: keluarga, umur dan jenis kelamin, (2) organisasi meliputi : sumber daya, kepemimpinan, imbalan dan prosedur kerja, tim work dan (3) psikologi meliputi: persepsi, sikap, kepribadian dan motivasi serta komitmen. Lebih dari itu, adapun yang mempengaruhi faktor-faktor kinerja dalam suatu organisasi adalah faktor kemampuan dan faktor motivasi.

Berdasarkan pendapat di atas maka dapat dikatakan bahwa komitmen, pendapatan atau penghasilan serta kebersamaan dalam tim kerja merupakan faktor yang mempengaruhi kinerja pegawai dalam bekerja.

\section{Komitmen Pegawai}

Menurut Mathis dan Jackson dalam Sopiah (2008: 155) komitmen adalah derajat yang mana karyawan percaya dan menerima tujuan-tujuan organisasi dan akan tetap tinggal atau tidak akan meninggalkan organisasi. Kemudian Mowday dalam Sopiah (2008: 156 - 157) menyebut komitmen kerja pegawai sebagai istilah lain dari komitmen organisasional menurutnya, komitmen merupakan 
dimensi perilaku penting yang dapat digunakan untuk menilai kecenderungan karyawan untuk bertahan sebagai anggota organisasi. Komitmen merupakan identifikasi dan keterlibatan seseorang yang relatif kuat terhadap organisasi. Komitmen adalah keinginan anggota organisasi untuk tetap mempertahankan keanggotaannya dalam organisasi dan bersedia berusaha keras bagi pencapaian tujuan organisasi.

Selain itu juga Bashaw dan Grant dalam Sopiah (2008: 156) menyatakan komitmen mencakup kebanggaan anggota, kesetiaan anggota dan kemauan anggota pada organisasi. Kemudian Knoop dalam Sopiah (2008: 156) menyebutkan komitmen sebagai keberpihakan dan loyalitas karyawan terhadap organisasi dan tujuan organisasi. Robbin dalam Sopiah (2008: 156) mendefinisikan komitmen pegawai sebagai suatu sikap yang merefleksikan perasaan suka atau tidak suka dari karyawan terhadap organisasi. O'Reilly dalam Sopiah (2008: 156) menyebutkan komitmen pegawai pada organisasi sebagai ikatan kejiwaan individu terhadap organisasi yang mencakup keterlibatan kerja, kesetiaan dan perasaan percaya terhadap nilai-nilai organisasi.

Steer dan Porter dalam Sopiah (2008: 156) menyatakan bahwa suatu bentuk komitmen yang muncul bukan hanya bersifat loyalitas yang pasif, tetapi juga melibatkan hubungan yang aktif dengan organisasi kerja yang memiliki tujuan memberikan segala usaha demi keberhasilan organisasi yang bersangkutan. Timpe dalam Pangabean (2001:137) menyatakan bahwa komitmen adalah mematuhi segala sesuatu kesepakatan yang telah dibuat (kedisiplinan) tanpa dilanggar. Konsep ini diartikan bahwa komitrnen merupakan kedisiplinan seorang pegawai terhadap peraturan-peraturan di dalam organisasi yang telah disepakati bersama. Dalam kehidupan sehari-hari komitmen sering diartikan sebagai suatu kesepakatan. Mengenai hal ini Gibson dalam Pangabean (2001:137) mengemukakan bahwa komitmen adalah rasa identifikasi dan loyalitas atau kesetiaan yang dinyatakan oleh seorang pegawai terhadap organisasi. Komitmen memberikan rasa tanggung jawab terhadap pekerjaan yang dilakukan seseorang.

Menurut Robbins (2003: 92), "Komitmen pegawai didefinisikan sebagai suatu keadaan dimana seorang pegawai memihak pada suatu organisasi tertentu dan tujuan-tujuannya serta berniat memelihara keanggotaan dalam organisasi itu". Komitmen pada organisasi yang tinggi dapat diartikan bahwa pemihakan pegawai (loyalitas) pada organisasi yang memperkerjakannya adalah tinggi.

Dari pendapat di atas, dapat disimpulkan bahwa komitmen pegawai adalah sebagai suatu keadaan dimana seorang pegawai memihak pada suatu organisasi tertentu dan tujuan-tujuannya serta berniat memelihara keanggotaan dalam organisasi itu. Menurut Sopiah (2008: 157) menyatakan komitmen pegawai merupakan suatu ikatan psikologis karyawan pada organisasi yang ditandai: (1) kepercayaan dan penerimaan yang kuat atas tujuan dan nilai-nilai organisasi, (2) kemauan untuk mengusahakan pencapaian kepentingan organisasi, dan (3) keinginan yang kuat untuk mempertahankan keanggotaan organisasi. Luthans (2005:252) menyatakan bahwa komitmen pegawai mengacu pada loyalitas pegawai pada organisasi dan ditentukan oleh sejumlah variabel orang, organisasi, dan non organisasi. Komitmen secara umum mempunyai tiga komponen: (afektif) 
pendekatan emosi, berkelanjutan (biaya meninggalkan organisasi) dan normatif (kewajiban untuk bertahan).

Lebih lanjut Luthans (2005:249) menyatakan bahwa sebagai sikap, komitmen pegawai paling sering didefinisikan sebagai: (1) keinginan kuat untuk tetap sebagai anggota organisasi tertentu, (2) keinginan untuk berusaha keras sesuai keinginan organisasi dan (3) keyakinan tertentu dan penerimaan nilai dan tujuan organisasi. Setiap pegawai memiliki dasar dan tingkah laku yang berbeda berdasarkan komitmen organisasi yang dimilikinya. Pegawai yang memiliki komitmen organisasi dengan dasar afektif memiliki tingkah laku berbeda dengan pegawai yang berdasarkan continuance. Pegawai yang ingin menjadi anggota akan memiliki keinginan untuk menggunakan usaha yang sesuai dengan tujuan organisasi. Sebaliknya, mereka yang terpaksa menjadi anggota akan menghindari kerugian finansial dan kerugian lain, sehingga mungkin hanya melakukan usaha yang tidak maksimal. Sementara itu, komponen normatif yang berkembang sebagai hasil dari pengalaman sosialisasi, tergantung dari sejauh apa perasaan kewajiban yang dimiliki pegawai. Komponen normatif menimbulkan perasaan kewajiban pada pegawai untuk memberi balasan atas apa yang telah diterimanya dari organisasi.

Pada dasarnya setiap orang mempunyai komitmen dalam melaksanakan suatu pekerjaan, namun ada yang memiliki komitmen yang tinggi terhadap pekerjaan dan ada pula yang rendah. Tinggi rendahnya komitmen dipengaruhi oleh tingkat perkembangan dan proses kejiwaan seseorang. Israil dalam Pangabean (2001:137) menyatakan bahwa komitmen seseorang itu dapat bertambah atau berkurang terhadap pekerjaannya, dan sangat dipengaruhi oleh sikap. Sikap positif terhadap pekerjaan akan membuat seseorang senang bekerja. Jika seseorang memiliki komitmen yang tinggi terhadap pekerjaan maupun organisasinya, maka pencapaian tujuan yang diharapkan akan lebih efektif dan efisien. Sebaliknya jika komitmen kerja seorang pegawai rendah, maka akan menghambat kelancaran pencapaian tujuan organisasi.

Pegawai yang mempunyai komitmen tinggi terhadap pekerjaannya akan bersemangat, berdisiplin tinggi dan sekaligus berkesempatan untuk meningkatkan profesionalisme dan produktivitas kerja. Komitmen kerja yang tinggi juga memungkinkan bagi pegawai untuk bekerja keras menghadapi tantangan dan hambatan. Komitmen juga menjadikan sasaran pegawai dan sasaran organisasi menjadi satu dan sejalan. Seorang pegawai yang betul-betul berpegang pada komitmen bersedia melakukan pengorbanan. Dengan kata lain pegawai yang berkomitmen tinggi adalah patriot organisasi dan pengobar semangat yang alami.

Dari beberapa pendapat di atas, Sopiah, Luthans dan Pangabean menyimpulkan bahwa komitmen pegawai adalah suatu ikatan psikologis karyawan pada organisasi yang ditandai dengan adanya: Kepercayaan dan penerimaan yang kuat atas tujuan dan nilai-nilai organisasi. Kemauan untuk mengusahakan tercapainya kepentingan organisasi. Keinginan yang kuat untuk mempertahankan kedudukan sebagai anggota organisasi. Kesetiaan karyawan pada organisasi. Kebanggaan karyawan pada organisasi 


\section{Pendapatan}

Kemudian menurut dewan penelitian pengupahan nasional dalam Husnan (2000: 138) upah ialah suatu penerimaan sebagai suatu imbalan dari pemberian kerja kepada penerima kerja untuk suatu pekerjaan atau jasa yang telah dan akan dilakukan, berfungsi sebagai jaminan kelangsungan kehidupan yang layak bagi kemanusiaan dan produksi dinyatakan atau dinilai dalam bentuk uang yang ditetapkan menurut suatu persetujuan, undang-undang dan peraturan dan dibayarkan atas dasar suatu perjanjian kerja antara pemberi kerja dan penerima kerja. Pendapatan merupakan salah satu jenis penghargaan yang dikaitkan dengan kinerja. Menurut Long dalam Widyastuty (2007: 20) pendapatan merupakan bagian dari upah berdasarkan kinerja (performance pay) yang diberikan dalam bentuk uang dan ditetapkan berdasarkan prestasi. Semakin tinggi prestasi kerjanya, semakin besar pula Pendapatan yang diberikan.

Menurut Agency Theory dalam Widyastuty (2007: 21) pendapatan digunakan untuk mendorong karyawan dalam memperbaiki kualitas dan kuantitas hasil kerjanya. Apabila pendapatan yang diterima tidak dikaitkan dengan prestasi kerja, tetapi bersifat pribadi, maka karyawan akan merasakan adanya ketidakadilan. Dengan adanya ketidakadilan tersebut akan mengakibatkan ketidakpuasan yang pada akhirnya akan mempengaruhi perilaku. Namun menurut para peneliti gaji berdasarkan kinerja tidak selalu cocok untuk semua jenis pekerjaan. Menurut Ruky dalam Widyastuty (2007: 23), dalam banyak pekerjaan, pengukuran prestasi kerja yang tepat tidak mungkin dilakukan dan desain serta pelaksanaannya rumit. Konsep tentang pendapatan telah diperkenalkan oleh Frederick Taylor pada akhir tahun 1800 dalam Widyastuty (2007: 23) menyatakan bahwa yang dinamakan pendapatan adalah kompensasi yang mengaitkan gaji dengan produktivitas.

Menurut Handoko (2001:176) menyatakan bahwa pendapatan merupakan penghargaan dalam bentuk finansial yang diberikan kepada mereka yang dapat bekerja melampui standar yang telah ditentukan. Istilah sistem pendapatan pada umumnya digunakan untuk menggambarkan rencana-rencana pembayaran upah yang dikaitkan baik secara langsung maupun tidak langsung dengan standar produktivitas karyawan. Karyawan yang bekerja dibawah sistem pendapatan berarti prestasi kerja mereka menentukan baik secara keseluruhan atau sebagian penghasilan mereka. Terdapat keuntungan-keuntungan yang didapat apabila merencanakan pemberian perfomance pay yang dirancang dengan tepat menurut Long dalam Widyastuty (2007: 20) yaitu: Dapat dijadikan sebagai kunci dalam berperilaku dan peningkatan motivasi untuk mencapai prestasi. Mengurangi kebutuhan akan bentuk-bentuk mekanisme untuk mengontrol perilaku karyawan. Menciptakan minat dalam diri karyawan untuk berprestasi dan mencari informasi tentang tingkat prestasi terbaru. Mendukung strategi manajemen dan pencapaian tujuan organisasi.

Fungsi utama dari Pendapatan adalah untuk memberikan tanggungjawab dan dorongan kepada karyawan. Pendapatan menjamin bahwa karyawan akan mengarahkan usahanya untuk mencapai tujuan organisasi. Sistem pendapatan yang efektif mengukur usaha karyawan dan penghargaan yang didistribusikan secara adil.Menurut Widyastuty (2007: 21) usaha-usaha dapat dinilai dengan cara: 
Perilaku karyawan dapat dimonitor dan penghargaan berkaitan dengan perilaku tersebut. Apabila perilaku dengan mudah dapat diukur dan dimengerti, maka monitoring menjadi lebih murah dan lebih tepat. Apabila pembayaran karyawan sebagian besar berkaitan dengan perilakunya di tempat kerja, maka cara ini disebut Behaviour Control. Hasil kerja (output) dapat diukur dan tingkat output itu menentukan penghargaan. Cara pengukuran berdasarkan hasil kerja disebut output control. Jenis jenis pendapatan meliputi : 1. Pendapatan individu. Pendapatan individu bertujuan untuk memberikan penghasilan tambahan selain gaji pokok bagi individu yang dapat mencapai standar prestasi tertentu. Insentif individu dapat diberikan berdasarkan kuantitas hasil kerja atau berdasarkan waktu (timing). 2. Pendapatan kelompok. Pendapatan kelompok merupakan pendapatan yang diberikan karena menghasilkan sebuah produk yang membutuhkan kerjasama dengan orang lain.

Terdapat tiga cara pembayaran Pendapatan kelompok yaitu : Seluruh anggota menerima pembayaran yang sama dengan pembayaran yang diterima oleh mereka yang paling tinggi prestasinya. Seluruh anggota menerima pembayaran yang sama dengan pembayaran yang diterima oleh mereka yang paling rendah prestasinya. Seluruh anggota menerima pembayaran yang sama dengan rata rata pembayaran yang diterima oleh kelompok. Menurut Locke dalam dalam Widyastuty (2007: 22) menyatakan bahwa pendapatan berupa uang lebih dapat meningkatkan produktivitas dibandingkan dengan teknik-teknik lainnya, seperti penetapan tujuan, partisipasi karyawan dalam pengambilan keputusan dan pemerkayaan pekerjaan (job enrichment). Adapun syarat-syarat yang patut dipenuhi dalam pemberian pendapatan agar tujuan pemberian pendapatan dapat diwujudkan sebagai berikut : Sederhana, peraturan dari sistem pendapatan haruslah singkat, jelas dan dapat dimengerti. Spesifik, karyawan perlu tahu dengan tepat apa yang diharapkan untuk mereka yang lakukan. Dapat dicapai, setiap karyawan seharusnya mempunyai kesempatan yang masuk akal untuk memperoleh sesuatu. Dapat diukur, sasaran yang dapat diukur merupakan dasar untuk menentukan rencana pendapatan.

Sebuah pendapatan harus dirancang sedemikian rupa sehingga memenuhi kebutuhan dan situasi tertentu yang spesifik. Sistem pemberian pendapatan pada masing-masing organisasi berbeda, dimana sistem pendapatan dapat berjalan dengan baik pada satu organisasi, mungkin akan gagal diterapkan pada organisasi yang lain. Program pendapatan yang terbaikpun tetap akan mempunyai beberapa hambatan pada waktu diterapkan pertama kali dan membutuhkan beberapa penyesuaian sebelum akhirnya menghasilkan apa yang diharapkan. Menurut Fatkhurahman (2018) pendapatan berkaitan dengan masalah kinerja yang dicapai dan diharapkan tercapai.

Program pendapatan yang baik memang cenderung meningkatkan prestasi individu dan produktivitas. Tetapi beberapa program, terutama program yang menekankan prestasi individu, justru menghambat peningkatan output karena terjadi "kolusi" antara sesama pekerja. Alasan mereka membuat begitu adalah adanya kecurigaan di antara para pekerja/karyawan bahwa output yang tidak dibatasi atau dihambat justru akan menyebabkan organisasi menurunkan besarnya pendapatan atau memperkecil kesempatan untuk berpindah penugasan. Agar 
program pendapatan yang kita rancang efektif, kita harus berusaha keras menghilangkan kecurigaan pekerja tersebut.

Kemudian apabila berbicara mengenai pendapatan, maka tidak bisa dilepaskan dengan pembicaraan kompensasi atau upah sebab pendapatan merupakan bagian dari sistem kompensasi. Terdapat banyak pendapat yang menyampaikan tentang kompensasi antara lain: Moekijat (2001: 161) menjelaskan kompensasi adalah apa yang diterima pegawai sebagai pertukaran pekerjaannya. Apakah itu upah jam-jaman atau gaji berkala, bagian personalia biasanya merencanakan dan mengelola kompensasi pegawai. Apabila kompensasi itu dilaksanakan dengan cermat, maka pegawai kemungkinan besar akan merasa puas dan dimotivasi untuk mencapai tujuannya dari tenaga kerja yang efektif. Akan tetapi apabila pegawai menerima kompensasi yang tidak memadai, maka pelaksanaan pekerjaan, motivasi, dan kepuasan mungkin akan berkurang.

Program kompensasi memelihara sumber daya manusia dari suatu organisasi. Apabila upah dan gaji tidak dikelola dengan baik, maka perusahaan mungkin akan kehilangan pegawai-pegawai dan biaya yang dikeluarkan untuk menarik, memilih dan mengembangkan mereka. Meskipun pegawai-pegawai tidak berhenti dari pekerjaan, mereka mungkin merasa tidak puas terhadap perusahaan.Ketidakpuasan timbul karena kebutuhan pegawai dipengaruhi oleh tingkat pembayaran yang mutlak dan relatif (Moekijat, 2001: 162). Jumlah pembayaran total atau mutlak terlalu rendah, maka pegawai tidak dapat memenuhi fisiologis atau kebutuhan keamanannya. Dalam masyarakat industri, tingkat pembayaran absolut biasanya cukup tinggi untuk memenuhi kebutuhan dasarnya, sekurang-kurangnya minimal. Suatu sumber ketidakpuasan yang tidak umum memusatkan pada pembayaran relatif, yakni pembayaran pegawai dibandingkan dengan pembayaran dari pegawai lain.

Tingkat pembayaran yang mutlak dan yang relatif juga dapat mengandung akibat-akibat yang negatif bagi organisasi. Dalam kejadian-kejadian tertentu, keinginan akan pembayaran yang lebih banyak dapat melibatkan pegawaipegawai mencari jabatan atau pekerjaan baru. Daya tarik yang lebih rendah dari jabatan-jabatan mereka dapat menimbulkan ketidakpuasan jabatan, ketidakhadiran atau akibat-akibat lain yang tidak diinginkan. Bahkan pembayaran upah atau gaji yang lebih banyak dari semestinya dapat merugikan organisasi dan orangorangnya. Biaya kompensasi yang tinggi dapat mengurangi kedudukan bersaing majikan dan kemampuan mendatang untuk memenuhi kebutuhan pembayaran. Bagi pegawai-pegawai yang dibayar lebih dari semestinya, mereka mungkin merasa gelisah, salah dan tidak senang. Selanjutnya oleh Moekijat (2001: 137) kompensasi dibedakan dengan gaji atau upah. Kompensasi adalah imbalan jasa yang diberikan kepada pegawai, karena yang bersangkutan telah memberikan sumbangan untuk mencapai tujuan organisasi. Dalam istilah kompensasi termasuk gaji, upah, perumahan pegawai, pakaian, tunjangan pangan dan tunjangantunjangan lainnya.

Menurut Husnan (2000: 138) upah adalah tiap-tiap pembayaran berupa uang yang diterima pekerja sebagai ganti pekerjaan. Kemudian juga berupa perumahan, makanan, bahan makanan dan pakaian secara percuma, bonus dan lain sebagainya. Upah dalam arti yang sempit dipergunakan untuk menunjukkan 
pembayaran yang diberikan kepada pegawai jam-jaman atau pegawai yang bukan pegawai tata usaha dan pegawai-pegawai lainnya yang pekerjaanya tidak melakukan pengawasan. Upah yang sesungguhnya atau sering disebut upah saja adalah dasar upah kali jam kerja (upah berdasarkan waktu) atau dasar upah kali satuan yang dihasilkan (upah satuan atau upah borongan atau upah pendapatan). Upah riil menunjukkan daya beli pembayaran berupa uang, premi, tetapi tidak termasuk potongan untuk kesejahteraan sosial, pajak penghasilan, surat obligasi, asuransi dan beban-beban lainnya. Dengan kata lain, upah bersih adalah pendapatan dikurangi potongan pajak, kesejahteraan sosial, asuransi iuran sarikat kerja, sumbangan-sumbangan dan lain-lainnya.

Berdasarkan pendapat di atas, jelas dapat diketahui bahwa pendapatan adalah tingkat hasil yang dicapai oleh pegawai dalam bekerja pendapatan ini berupa materi yang pemberiannya Menurut Locke dalam Ruky dalam Widyastuty (2007: 22) menyatakan pendapatan berupa uang lebih dapat meningkatkan produktivitas dibandingkan dengan teknik-teknik lainnya, seperti penetapan tujuan, partisipasi karyawan dalam pengambilan keputusan dan pemerkayaan pekerjaan (job enrichment). Adapun syarat-syarat yang patut dipenuhi dalam pemberian pendapatan agar tujuan pemberian pendapatan dapat diwujudkan sebagai berikut : Sederhana, peraturan dari sistem pendapatan haruslah singkat, jelas dan dapat dimengerti. Spesifik, karyawan perlu tahu dengan tepat apa yang diharapkan untuk mereka yang lakukan. Dapat dicapai, setiap karyawan seharusnya mempunyai kesempatan yang masuk akal untuk memperoleh sesuatu. Dapat diukur, sasaran yang dapat diukur merupakan dasar untuk menentukan rencana pendapatan.

Kemudian Siagian (2008: 257-258) menyatakan bahwa imbalan yang efektif sebelumnya perlu melakukan: analisis terhadap pekerjaan yang dilakukan karyawan, melakukan penilaian pekerjaan, melakukan survei berbagai sistem imbalan dan menentukan harga setiap pekerjaan. Kemudian Moekijat (2001: 161) menyatakan penilaian terhadap imbalan dapat dilakukan dengan melakukan evaluasi terhadap jabatan, kemudian survey upah dan gaji dan memberi harga pada jabatan-jabatan. Berdasarkan pendapat mengenai ukuran pendapatan di atas, maka dapat disimpulkan pendapatan adalah jumlah uang yang diterima oleh seorang pekerja dari apa yang dikerjakan dengan kesepakatan tertentu. Dengan dimensi sederhana, peraturan dari sistem pendapatan haruslah singkat, jelas dan dapat dimengerti; spesifik, karyawan perlu tahu dengan tepat apa yang diharapkan untuk mereka yang lakukan; dapat dicapai, setiap karyawan seharusnya mempunyai kesempatan yang masuk akal untuk memperoleh sesuatu dan dapat diukur, sasaran yang dapat diukur merupakan dasar untuk menentukan rencana pendapatan.

\section{Kebersamaan}

Menurut Tika (2005: 136) kebersamaan/keterlibatan merupakan faktor kunci dalam budaya organisasi dan dijelaskan bahwa kebersamaan merupakan strategi manajemen bagi kinerja perusahaan yang efektif dan strategi karyawan untuk lingkungan kerja yang baik. Menurut Tracy dalam Sopiah (2008: 41) kebersamaan merupakan kegiatan yang dikelola dan dilakukan sekelompok orang 
yang bergabung dalam suatu organisasi. Kebersamaan ini dapat meningkatkan kerjasama dan komunikasi di dalam dan di antara bagian-bagian perusahaan. Selain itu juga menurut Dewi dalam Sopiah (2008: 41) kebersamaan adalah bentuk kerja dalam kelompok yang harus diorganisasi dan dikelola dengan baik. Dalam bekerja kebersamaan menjadi hal yang mutlak dengan maksud membangun sama rasa dalam bekerja.

Menurut West dalam Sopiah (2008: 41) berdasarkan perspektif individu, dengan masuknya individu ke dalam kelompok, maka hal tersebut akan menambah semangat juang/motivasi untuk mencapai suatu prestasi yang mungkin tidak akan pernah dapat dicapai seorang diri oleh individu tersebut. Hal ini dapat terjadi karena tim mendorong setiap anggotanya untuk memiliki wewenang dan tanggung jawab sehingga menimbulkan harga diri setiap orang. Keberadaan seseorang akan lebih bernilai apabila ia dapat memberi kontribusi pada tim dan anggota tim juga menghargai kontribusi berupa tenaga dan pikirannya. Berdasarkan pendapat di atas, maka dapat disimpulkan kebersamaan merupakan suatu sikap perilaku yang ditunjukkan anggota kelompok dalam mencapai suatu tujuan tertentu. Menurut Sopiah (2008: 41) berbagai faktor yang mempengaruhi kebersamaan yaitu kebersamaan nilai dan tujuan, keberhasilan dalam mencapai tujuan, status atau citra kelompok, kecocokan terhadap normanorma, daya tarik pribadi, persaingan antar kelompok serta pengakuan dan penghargaan. Kesamaan nilai dan tujuan, kelompok akan menjadi lebih padu dalam kebersamaan tim jika setiap anggota kelompok memiliki kesamaan dalam nilai yang dianut dan kesamaan dalam tujuan yang ingin diraih. Keberhasilan dalam mencapai tujuan, keberhasilan dalam mencapai tujuan bisa menimbulkan spirit bagi kelompok untuk menjadi semakin solid karena keberhasilan memunculkan rasa senang, bahagia dan bangga. Perasaan ini mendorong setiap anggota kelompok untuk dapat mengulangi perasaan-perasaan itu. Status atau citra kelompok, status kelompok yang positif di mata lingkungan akan memacu anggota kelompok untuk semakin padu, saling menjaga agar status kelompok bisa tetap baik dilingkungannya. Penyelesaian perbedaan, dalam suatu kelompok terdapat banyak individu. Setiap individu berbeda satu sama lain. Oleh karena itu jika perbedaan muncul dan mengakibatkan terjadinya konflik dalam kelompok maka konflik itu akan dapat dikelola dengan baik. Hal ini akan memacu anggota kelompok untuk menjadi semakin padu. Kecocokan terhadap norma-norma, dalam kelompok pasti ada norma kelompok. Jika norma kelompok tersebut cocok dengan norma yang dianut anggota kelompok tersebut maka kelompok itu akan semakin padu. Daya tarik pribadi, seseorang masuk dalam suatu kelompok bisa disebabkan oleh ketertarikan dia pada pribadi pemimpin atau anggota kelompoknya. Persaingan antar kelompok, persaingan antar kelompok bisa mengakibatkan keanggotaan suatu kelompok menjadi semakin solid. Hal ini karena tiap kelompok bersaing dan tiap kelompok ingin jadi pemenang. Pengakuan dan penghargaan, jika kelompok mendapat pengakuan dan penghargaan dari lingkungan, hal itu juga bisa berdampak terhadap kebersamaan kelompok. 


\section{METODE}

Penelitian ini menggunakan metode kuantitatif, yaitu penelitian yang berusaha mendeskripsikan suatu gejala, peristiwa dan kejadian yang menjadi pusat perhatiannya untuk selanjutnya dianalisis antara variabel independent (variabel bebas) yang terdiri dari variabel $\mathrm{X}_{1}$ (komitmen), variabel $\mathrm{X}_{2}$ (pendapatan) dan $\mathrm{X}_{3}$ (kebersamaan). Variabel dependent (variabel terikat) penelitian ini yaitu kinerja pegawai $(\mathrm{Y})$.

Populasi dalam penelitian ini adalah seluruh pegawai sekwan DPRD Kota Pekanbaru, yang berjumlah 56 orang. Sugiyono (2005:91) menyatakan bahwa sampel adalah bagian dari jumlah dan karakteristik yang dimiliki oleh populasi. Mengingat populasinya yang relatif terjangkau yaitu sebanyak 56 orang maka seluruh populasi dijadikan sampel (sensus). Untuk mendapatkan data dan informasi serta bahan-bahan lainnya yang diperlukan dan berhubungan dengan penelitian ini, maka teknik pengumpulan data dilakukan dengan cara sebagai berikut: Penelitian lapangan, dilakukan untuk mendapatkan data primer penelitian dengan menyebarkan melalui penyediaan angket berupa daftar pertanyaan maupun pernyataan yang diberikan kepada setiap responden yang telah ditetapkan terlebih dahulu untuk dijawab atau diisi. Untuk keterangan yang lebih mendalam tentang permasalahan yang diteliti, daftar pertanyaan yang dibuat tersebut dibuat sedetail mungkin, berisikan pertanyaan tentang fakta, pendapat dan informasi.

Kuesioner berisi pernyataan yang mempunyai nilai, yaitu: nilai 5 (sangat setuju/sangat baik >80\%), skor 4 (setuju/baik 61\% - 80\%) ), skor 3 (cukup 40\% $60 \%$ ), skor 2 (kurang setuju/kurang baik 21\% - 40\%) dan skor 1 (tidak setuju/tidak baik < 20\%).

Studi kepustakaan, dilakukan dengan mengumpulkan bahan-bahan tertulis, data dari dokumen dan studi literatur, yakni dengan mempelajari dan menganalisa sejumlah bahan-bahan tertulis, baik pendapat para ahli maupun dari perundangundangan yang berlaku serta literatur-literatur yang dianggap memiliki relevansi dengan penelitian dan dokumen yang terkait dengan masalah yang dikaji sering diperlukan. Kuesioner yang akan digunakan untuk mengumpulkan data penelitian terlebih dahulu di uji validitas dan reliabilitasnya. Teknik analisis data yang digunakan adalah analysis jalur.

\section{HASIL}

Berdasarkan hasil perhitungan secara keseluruhan, maka dapat dimaknai dan dibahas sehingga memberikan informasi secara objektif sebagai berikut: Hipotesis 1 yaitu "komitmen berpengaruh signifikan terhadap kebersamaan pegawai Sekretariat DPRD Kota Pekanbaru". Dari hasil pengolahan data diketahui besarnya pengaruh komitmen $\left(\mathrm{X}_{1}\right)$ terhadap kebersamaan $\left(\mathrm{X}_{3}\right)$ dinyatakan dengan koefisien jalur sebesar 0,350. Ini menunjukkan bahwa komitmen tidak begitu mempengaruhi kebersamaan yang dirasakan pegawai dalam bekerja. Temuan penelitian menunjukkan bahwa pegawai kurang menerapkan nilai organisasi dalam melayani masyarakat. Dimana kemauan pegawai dalam menerapkan nilai yang terkandung dalam organisasi masih rendah dan ini menjadi hambatan kepada pegawai dalam menumbuhkan kreatifitas dan inovasi dalam bekerja. Hipotesis 2 yaitu "pendapatan berpengaruh signifikan 
terhadap kebersamaan pegawai Sekretariat DPRD Kota Pekanbaru". Dari hasil pengolahan data diketahui besarnya pengaruh pendapatan $\left(X_{2}\right)$ terhadap kebersamaan $\left(\mathrm{X}_{3}\right)$ dinyatakan dengan koefisien jalur sebesar 0,560. Ini menunjukkan pengaruh pendapatan terhadap kebersamaan lebih besar apabila dibandingkan dengan pengaruh komitmen terhadap kebersamaan. Dengan adanya pendapatan akan menciptakan kebersamaan dalam bekerja. Temuan penelitian menunjukkan bahwa pendapatan yang diterima pegawai belum memadai sehingga sesama pegawai kurang saling menghargai dalam satu kelompok. Hal ini tentunya mempengaruhi kebersamaan pegawai dalam bekerja.

Hipotesis 3 yaitu komitmen berpengaruh signifikan terhadap kinerja pegawai Sekretariat DPRD Kota Pekanbaru". Dari hasil pengolahan data diketahui besarnya pengaruh komitmen $\left(\mathrm{X}_{1}\right)$ yang secara langsung mempengaruhi kinerja (Y) dinyatakan dengan koefisien jalur sebesar 0,260. Ini menunjukkan bahwa komitmen tidak begitu mempengaruhi kinerja pegawai. Hal ini disebabkan karena adanya faktor lain yaitu prendapatan yang lebih besar pengaruhnya terhadap kinerja. Hipotesis 4 yaitu "pendapatan berpengaruh signifikan terhadap kinerja pegawai Sekretariat DPRD Kota Pekanbaru". Dari hasil pengolahan data diketahui besarnya pengaruh pendapatan (X2) yang secara langsung mempengaruhi kinerja (Y) dinyatakan dengan koefisien jalur sebesar 0,316. Temuan penelitian menunjukkan bahwa pegawai yang memperoleh hasil kerja yang baik diperlakukan sama dengan mereka yang tidak berprestasi dan ini dapat memberikan dampak buruk kepada kinerja pegawai.

Hipotesis 5 yaitu kebersamaan berpengaruh signifikan terhadap kinerja pegawai Sekretariat DPRD Kota Pekanbaru". Dari hasil pengolahan data diketahui besarnya pengaruh kebersamaan $\left(X_{3}\right)$ yang secara langsung mempengaruhi kinerja (Y) dinyatakan dengan koefisien jalur sebesar 0,329. Pengaruh kebersamaan terhadap kinerja relatif lebih besar dibandingkan pengaruh variabel komitmen dan pendapatan terhadap kinerja. Hal ini disebabkan dengan adanya kebersamaan akan menimbulkan suasana yang kondusif bagi pegawai dalam bekerja sehingga mempengaruhi hasil kerja pegawai. Pengaruh tidak langsung $\mathrm{X} 1$ terhadap $\mathrm{Y}$ melalui $\mathrm{X}_{3}$ sebesar $\rho \mathrm{x}_{3} \mathrm{X}_{1}$. $\rho \mathrm{yx}_{3}=(0,350) .(0,329)=0,115$. Dengan demikian pengaruh total $X_{1}$ terhadap $Y$ adalah sebesar 0,115 . Selanjutnya pengaruh tidak langsung $\mathrm{X}_{2}$ terhadap $\mathrm{Y}$ melalui $\mathrm{X}_{3}$ sebesar $\rho \mathrm{x}_{3} \mathrm{X}_{2}$. $\rho \mathrm{xx}_{3}=$ $(0,560) \cdot(0,329)=0,184$. Dengan demikian pengaruh total $X_{2}$ terhadap $Y$ adalah sebesar 0,184 .

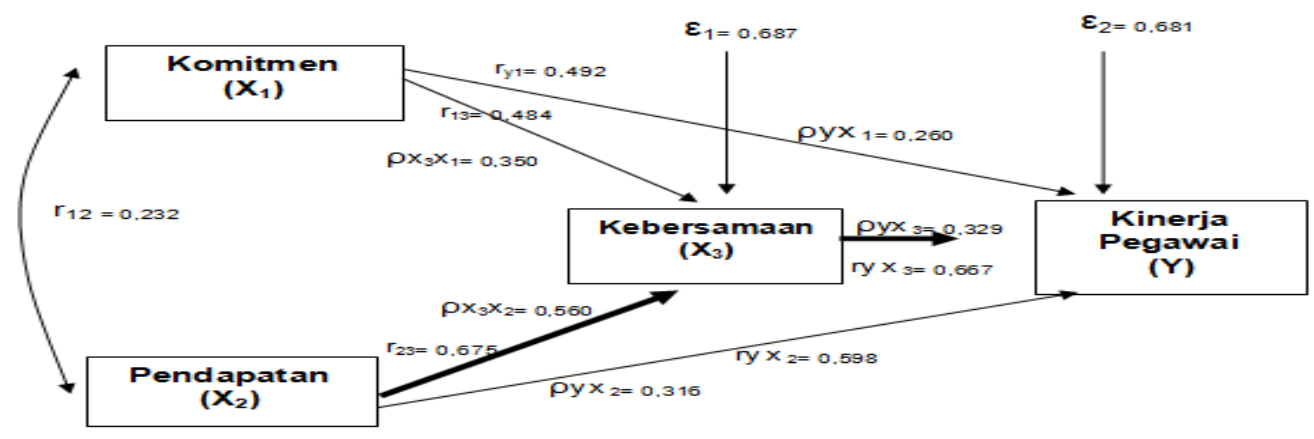


Tabel 1. : Koefisien jalur, pengaruh langsung, pengaruh tidak langsung, pengaruh total dan pengaruh bersama komitmen $\left(\mathrm{X}_{1}\right)$, pendapatan $\left(\mathrm{X}_{2}\right)$ dan kebersamaan $\left(\mathrm{X}_{3}\right)$ terhadap kinerja $(\mathrm{Y})$

\begin{tabular}{|c|c|c|c|c|c|}
\hline \multirow[b]{2}{*}{ Variabel } & \multirow[b]{2}{*}{$\begin{array}{l}\text { Koefisien } \\
\text { Jalur }\end{array}$} & \multicolumn{3}{|l|}{ Pengaruh } & \multirow{2}{*}{$\begin{array}{l}\text { Pengaruh } \\
\text { bersama } \\
\left(R^{2} \mathrm{yx}\right)\end{array}$} \\
\hline & & Langsung & $\begin{array}{l}\text { Tidak langsung } \\
\text { melalui } X_{3}\end{array}$ & Total & \\
\hline $\mathrm{X} 1$ & 0,260 & 0,260 & 0,329 & 0,115 & - \\
\hline $\mathrm{X} 2$ & 0,316 & 0,316 & 0,329 & 0,184 & - \\
\hline $\mathrm{X} 3$ & 0,329 & 0,329 & - & - & - \\
\hline$\varepsilon_{1}$ & 0,687 & 47,20 & - & - & - \\
\hline$\varepsilon_{2}$ & 0,681 & 46,38 & - & - & - \\
\hline $\mathrm{X}_{1}, \mathrm{X}_{2}$ dan $\mathrm{X}_{3}$ & - & - & - & - & 0,536 \\
\hline
\end{tabular}

Dari tabel di atas dapat dilihat besarnya pengaruh langsung variabel komitmen terhadap kinerja sebesar 0,260, sedangkan pengaruh tidak langsung yaitu melalui kebersamaan sebesar 0,329. Jadi total pengaruh komitmen terhadap kinerja sebesar 0,115 . Selanjutnya pengaruh langsung variabel pendapatan terhadap kinerja sebesar 0,316, sedangkan pengaruh tidak langsung yaitu melalui kebersamaan sebesar 0,329. Jadi total pengaruh komitmen terhadap kinerja sebesar 0,184. Dengan demikian diketahui jalur yang memberikan pengaruh yang lebih besar terhadap kinerja adalah variabel pendapatan melalui variabel kebersamaan.

\section{PEMBAHASAN}

Dari hasil perhitungan diketahui bahwa pengaruh pendapatan terhadap kinerja melalui kebersamaan lebih besar dibandingkan pengaruh komitmen terhadap kinerja melalui kebersamaan, dengan total pengaruh 0,184 . Hal ini disebabkan bekerja sebagai pegawai di Sekeretariat DPRD Kota Pekanbaru dengan tugas sebagai penatausahaan/manajemen kegiatan wakil rakyat yaitu berupa kegiatan-kegiatan rapat dan juga reses (dengar pendapat/menampung aspirasi masyarakat pada daerah pilihan pada masing-masing anggota dewan dengan waktu yang tidak menentu. Hal ini membutuhkan kekompakan/kebersamaan dari pegawai dalam melaksanakannya. Kebersamaan ini sangat dibutuhkan dalam rangka menyikapi atau merespon tuntutan masyarakat.

Selanjutnya dari hasil perhitungan diketahui variabel kebersamaan memberikan pengaruh yang paling besar terhadap kinerja yaitu sebesar 0,329. Kebersamaan membutuhkan dukungan pendapatan dan juga komitmen dari para pegawai dan pimpinan dalam melaksanakan suatu kegiatan. Dengan dukungan komitmen dan pendapatan akan menumbuhkan semangat kebersamaan sesama pegawai dan pada akhirnya akan menghasilkan kinerja yang optimal yaitu melayani kebutuhan manajemen anggota dewan. Kinerja pegawai menjadi salah satu penentu keberhasilan tugas dan fungsi anggota dewan. Dari hasil perhitungan diketahui bahwa pengaruh pendapatan terhadap kebersamaan lebih besar dibandingkan pengaruh komitmen terhadap kebersamaan. Ini menunjukkan bahwa 
pendapatan yang diterima pegawai belum memadai. Temuan penelitian menunjukkan bahwa penggajian tidak didasarkan pada prestasi kerja pegawai. Dimana pegawai yang bekerja lebih banyak mendapatkan gaji yang sama bila dibandingkan dengan pegawai yang kurang dalam bekerja. Menurut Bert dalam Pangabean (2002: 139), hubungan antara komitmen organisasi dengan kinerja karyawan bagi mereka yang kurang membutuhkan dana lebih kuat daripada bagi mereka yang membutuhkan dana.

Jika dilihat dari koefisien regresi diketahui pengaruh kebersamaan terhadap kinerja lebih besar (0.305) dibandingkan dengan pendapatan (0.224) dan komitmen pegawai (0.092). Sesuai dengan hasil penelitian dan pembahasan bahwa pegawai selalu mendapatkan kebanggan bekerja sebagai PNS dan penuh semangat dalam bekerja serta adanya kerinduan untuk datang ke kantor melakukan pekerjaan bersama rekan kerja, pegawai juga bangga menggunakan pakaian dinas pegawai negeri. Hal ini sejalan dengan yang disampaikan oleh Kelly dalam Danim (2004: 142) kebersamaan dalam kelompok sangat potensial menimbulkan kebahagiaan anggota kelompok, meski kebahagiaan sangat mungkin tidak berkorelasi langsung dengan produktivitas. Kebersamaan yang terbuka akan mengurangi rasa terpaksa dalam partisipasi, mempertinggi intensitas hubungan dan dengan demikian akan mempertinggi efektifitas kelompok. Kemudian kebersamaan yang terbuka dapat juga menghambat tugas kelompok, mengurangi keketatan rahasia dan akibatnya produktivitas kelompok dapat menurun dan dipertegas oleh Thoha (2008: 98-99) bahwa kebersamaan dalam bersikap akan memudahkan orang untuk berinterakasi antara yang satu dengan yang lainnya dan hal ini menimbulkan daya tarik untuk melakukan sesuatu kegiatan.

Selanjutnya dari penelitian yang dilakukan Rodiyah (2006) menunjukkan hasil bahwa variabel nilai kebersamaan berpengaruh terhadap motivasi dengan tingkat signifikansi sebesar $0,000(\mathrm{p}<0,05)$ dan mempengaruhi hasil kerja berupa kreatifitas bekerja dengan tingkat signifikansi sebesar $0,002(\mathrm{p}<0,05)$. Dengan demikian kebersamaan berpengaruh signifikan hasil kerja (kinerja). Sekretariat DPRD mempunyai fungsi vital dalam penyelenggaraan kegiatan DPRD. Dari hasil penelitian diketahui kebersamaan merupakan faktor dominan yang mempengaruhi kinerja. Dengan demikian, dalam bekerja, kebersamaan menjadi hal yang mutlak dengan maksud membangun sama rasa dalam bekerja sehingga pada akhirnya dapat meningkatkan kinerja pegawai. Apabila dilihat tempat pegawai bekerja yaitu Sekretariat DPRD, adanya kecenderungan bahwa pendapatan mempengaruhi komitmen pegawai dalam bekerja. Dimana apabila pendapatan menurun, maka komitmen pegawai dalam bekerja juga akan menurun.

\section{KESIMPULAN}

Pengaruh tidak langsung $\mathrm{X}_{1}$ terhadap $\mathrm{Y}$ melalui $\mathrm{X}_{3}$ sebesar $\rho \mathrm{x}_{3} \mathrm{x}_{1}$. $\rho \mathrm{yx}_{3}=$ $(0,350) .(0,329)=0,115$. Dengan demikian pengaruh total $X_{1}$ terhadap $Y$ adalah sebesar 0,115 . Selanjutnya pengaruh tidak langsung $X_{2}$ terhadap $Y$ melalui $X_{3}$ sebesar $\rho \mathrm{x}_{3} \mathrm{X}_{2} . \rho \mathrm{yx}_{3}=(0,560) .(0,329)=0,184$. Dengan demikian pengaruh total $\mathrm{X}_{2}$ terhadap Y adalah sebesar 0,184. Dengan demikian diketahui jalur yang memberikan pengaruh yang lebih besar terhadap kinerja adalah jalur variabel 
pendapatan melalui variabel kebersamaan. Temuan penelitian menunjukkan bahwa pendapatan yang diperoleh pegawai belum memadai dan juga sistem penggajian tidak didasarkan pada prestasi kerja pegawai. Dimana pegawai yang bekerja lebih banyak mendapatkan gaji yang sama bila dibandingkan dengan pegawai yang kurang dalam bekerja. Hal ini dapat mempengaruhi kebersamaan dalam bekerja dan pada akhirnya dapat mempengaruhi kinerja pegawai.

\section{DAFTAR PUSTAKA}

Cahyasumirat, Gunawan, 2006, Pengaruh profesionalisme dan komitmen organisasi terhadap kinerja internal auditor, dengan kepuasan kerja sebagai variabel intervening, Tesis, Universitas Diponegoro, Semarang.

Chatab, Nevizond, 2007, Profil Budaya Organisasi, mendiagnosis Budaya dan Merangsang Perubahan, Alphabeta, Bandung.

Daha, 2002, Faktor yang dapat berperan dalam mempengaruhi keberhasilan kinerja pelayanan publik yang sangat dominan adalah faktor kepemimpinan, sistem intensif dan kerjasama (Studi Kasus pada Kantor Pendaftaran Penduduk Kota Samarinda). Tesis.

Danim, Sudarwan, 2004, Motivasi, Kepemimpinan dan Efektifitas Kelompok, Rhineka Cipta, Jakarta.

Dessler, Garry, 2004, Manajemen Personalia, Edisi Ketiga, Erlangga, Jakarta.

FATKHURAHMAN, F. (2016). Kepuasan Berwirusaha Melalui Kemauan Untuk Berkarya Usaha Industri Kecil. Jurnal Ekonomi dan Bisnis Islam UIN Imam Bonjol, 1(2), 143-153.

Fatkhurahman, N. P. M. (2018). Pengaruh Jiwa Kewirausahaan dan Kemitraan Terhadap Kebijakan Bisnis dan Kinerja Pengelola Serta Dampaknya Pada Keunggulan Bersaing Industri Kecil Makanan di Propinsi Riau (Doctoral dissertation, Unpas).

Handoko, T. Hani, 2001, Manajemen, BPFE, Yogyakarta.

Husnan, Heidjrachman, Suad, 2000, Manajemen Personalia Edisi 4., BPFE Yogyakarta, Yogyakarta.

Lewa, Eka Idham Iip K, 2005, Pengaruh kepemimpinan, lingkungan kerja fisik dan kompensasi terhadap kinerja karyawan di PT Pertamina (Persero) daerah operasi hulu Jawa Bagian Barat Cirebon. Sinergi, Edisi khusus on Human Resourches. 
Luthans, 2005, Work Volvos and Commitment International, Journal Manpower, Vol 17.3.

Mangkunegara, Prabu, Anwar, 2002, Manajemen Sumber Daya Manusia Perusahaan., PT. Remaja Rosdakarya, Bandung.

Mathis dan Jackson, 2001, Manajemen Sumber Daya Manusia, Salemba Empat, Jakarta

Moekijat, 2001, Manajemen Personalia dan Sumber Daya Manusia, Mandar Maju, Bandung.

Muljani, Ninuk, 2002, Kompensasi sebagai motivator untuk meningkatkan kinerja karyawan, Jurnal manajemen \& kewirausahaan, Vol 4 Nomor 2 September 2002.

Pangabean, Mutiara, Sibarani, 2001, Manajemen Sumber Daya Manusia, Ghalia Indonesia, Bogor.

Purba, Debora Elfina dan Seniati, Ali nina Liche, 2004, Pengaruh Kepriadian dan komitmen organisasi terhadap organizational citizentship behaviour, Makara, Sosial Humaniora, Vol 8 Nomor 3, Desember 2004.

Risamasu, Ferdinand, 2007, Analisis faktor-faktor yang mempengaruhi kinerja karyawan perusahaan-perusahaan daerah provinsi Papua, Jurnal Analisis, Vol 4 Nomor 1, Maret 2007.

Riau, Sekolah Tinggi Ilmu Ekonomi. "Motivasi Perempuan Berwirausaha Melalui Kelompok Arisan Program Pemberdayaan Masyarakat (Pkk) Di Kota Pekanbaru."

Robbins, Sthepen, 2003, Perilaku Organisasi, Terjemahan Tim Indeks. Indeks Garamedia, Jakarta.

Robins, 2001, Teori Organisasi, Arcan, Jakarta.

Rodiyah, 2006, Pengaruh nilai kebersamaan budaya lokal dan lingkungan kerja terhadap hasil kerja pegawai di Badan Kepegawaian Daerah, Kabupaten Sidoarjo, Tesis, Unair. Surabaya.

Siagian, Sondang, 2008, Manajemen Sumber Daya Manusia, Bumi Aksara, Jakarta.

Sianipar dan Entang, 2001, Efektivitas Implementasi Kebijakan Otonomi Daerah, CV. Citra Utama, Depok. 
Soeprihanto, 2000, Responsivitas dan Akuntabilitas Sektor Publik, Dalam Jurnal Administrasi Negara (Volume 1 No. 2 Maret 2001), FIA Unibraw, Malang.

Sopiah, 2008, Perilaku Organisasional, Andi, Yogyakarta.

Sudiro, Ahmad, 2008, Pengaruh timbal balik antara kepuasan kerja dengan kepuasan keluarga dan komitmen kerja serta dampaknya terhadap prestasi kerja dan karir dosen, Jurnal manajemen dan kewirausahaanm, Vol. 10 Nomor 1, Maret 2008.

Sulasmi, Siti, 2009, Peran variabel perilaku belajar inovatif, intensitas kerjasama kelompok, kebersamaan visi dan rasa saling percaya dalam membentuk kualitas sinerji. Ekuitas, Vol 13 Nomor 2 Juni 2009.

Supriyono, 2006, Pengaruh variabel perantara komitmen organisasi dan partisipasi penganggaran terhadap hubungan antara usia dan kinerja manajer di Indonesia, Jurnal ekonomi dan bisnis, Vol 6 Nomor 1 Februari 2006.

Surya Dharma, 2004, Manajemen Kinerja, Falsafah Teori dan Penerapannya, Pustaka Pelajar, Yogyakarta.

Sutrisno, Edi, 2010, Budaya Organisasi, Kencana Prenada Media Group, Jakarta.

Teguh, Ambar Teguh Sulistiyani, 2003, Manajemen Sumber Daya Mausia, Konsep, Teori dan Pengembangan dalam Konteks Organisasi Publik, Graha Ilmu, Yogyakarta.

Thoha, Miftah, 2008, Perilaku Organisasi Konsep dasar dan Aplikasinya, RajaGrafindo Persada, Jakarta.

Tika. Moh. Prabu, 2005, Budaya Organisasi dan Peningkatan Kinerja Perusahaan, Bumi Aksara, Jakarta.

Widodo, 2001, Indikator Ekonomi, Dasar Perhitungan Perekonomian Indonesia, Kanisius, Yogyakarta.

Widyastuty, 2007, Pengaruh Insentif terhadap Prestasi Kerja Pegawai, Tesis, UNAIR.

Wirawan, 2008, Budaya dan Iklim Organisasi Teori Aplikasi Penelitian, Salemba Empat, Jakarta. 